\title{
PENERAPAN PEMBELAJARAN KOOPERATIF MODEL STAD UNTUK MENINGKATKAN KEMAMPUAN MENENTUKAN TOPIK DAN TEMA DALAM SUATU KARANGAN PADA SISWA KELAS IV SDN KEBUNAN I SUMENEP TAHUN PELAJARAN 2010-2011.
}

\author{
SUMIYATUN \\ Jurusan Pendidikan Bahasa dan Sastra Indonesia, Sekolah Tinggi Keguruan dan Ilmu \\ Pendidikan
}

\begin{abstract}
ABSTRAK
Upaya peningkatan mutu dan kualitas pendidikan untuk mengubah paradigma pembelajaran dari teacher centered menjadi student centered terus menerus dilakukan baik secara konvensional maupun inovatif. Membaca adalah salah satu di antaraempat komponen ketrampilan berbahasa.Pesan atau informasi yang disampaikan penulis melalui kata-kata bermakna dalam bentuk bahasa yang dituliskan dapat diperoleh melalui kegiatan membaca.Selain itu, dalam suatu karangan pasti memiliki topik dan tema tertentu.Cooperative Learning merupakan suatu teknik pembelajaran yang berusaha meningkatkan kemampuan siswa untuk bekerjasama dalam kelompok kecil, guna memaksimalkan kemampuan belajarnya.Model pembelajaran yang cukupefektifdankooperatifadalah model pembelajaran STAD (Student Teams AchivementDevisions). Tujuan dari penelitian ini adalah Mendeskripsikanperencanaan, pelaksanaan dan hasil penerapan pembelajaran kooperatif model STAD untukmaterimenentukantopikdantemadalamsuatukaranganpadasiswakelas IV SDN Kebunan I Sumenep. Jenis penelitian ini merupakan Penelitian Tindakan Kelas (PTK).Penelitian ini dilaksanakan dalam dua siklus, masing-masing siklus terdiri dari 4 tahap yaitu perencanaan tindakan (planning), pelaksanaan tindakan (action), observasi (observation), dan refleksi (reflection). Pelaksanaan siklus II dilaksanakan setelah mempelajari hasil refleksi pada siklus I.Pengumpulan data dilakukan dengan teknik observasi, wawancara, dokumentasi, dan tes. Hasil yang diperoleh dari penelitian ini adalah terdapat peningkatan nilai di atas KKM siswa kelas IV SDN Kebunan I untuk materi pokok menentukan topik atau tema mata pelajaran bahasa Indonesia dengan pendekatan teknik pembelajaran kooperatif STAD (cooperative learning) dari 14 anak menjadi 43 anak. Hasil observasi terhadap performa siswa, baik secara individu maupun kelompok menunjukkan hasil nilai di atas $\operatorname{KKM}(>60,00)$. Hal ini ditunjukkan dari rata-rata nilai individu sebesar 73, 15 dan nilai kelompok 86, 11 dari total nilai 100 dengan beberapa indikator yang telah ditentukan. Respon siswa terhadap materi pembelajaran menentukan topik atau tema dalam bahasa Indonesia melalui pendekatan pembelajaran kooperatifteknik STAD menunjukkan para siswa menyukai teknik ini karena memberikan suasana baru dan penghargaan yang memotivasi mereka dalam belajar, namun para siswa menyatakan juga belum terbiasa karena kedua teknik ini masih baru bagi mereka.
\end{abstract}

Kata Kunci: Menentukan topik dan tema, Pembelajaran Kooperatif (Cooperative Learning), Student Teams Achievment Devisions (STAD).

\section{PENDAHULUAN}

Upaya peningkatan mutu dan kualitas pendidikan terus menerus dilakukan baik secara konvensional maupun inovatif. Kompetensi yang diinginkan adalah kemampuan dalam bidang pengusaan pengetahuan, keterampilan dan nilai-nilai dasar yang direfleksikan dalam kebiasaan berfikir dan bertindak. Pembaharuan tersebut bertujuan untuk mengubah paradigma pembelajaran dari teacher centered menjadi student centered. Rumusan kompetensi yang diinginkan adalah apa yang diharapkan dapat diketahui, disikapi atau dilakukan siswa dalam tiap tingkatan kelas dan sekolah serta sekaligus menggambarkan kemajuan siswa yang dicapai secara bertahap dan berkelanjutan untuk menjadi kompeten dalam semua mata pelajaran.

Membaca adalah salah satu di antara empat komponen ketrampilan berbahasa, pada umumnya diperoleh seseorang melalui proses belajar yang cukup lama dan berkesinambungan di lembaga pendidikan sekolah. Pesan atau informasi yang disampaikan penulis melalui kata-kata bermakna dalam bentuk bahasa yang dituliskan dapat diperoleh 
melalui kegiatan membaca. Selain itu, dalam suatu karangan pasti memiliki topik dan tema tertentu. Dengan adanya suatu topik atau tema maka pesan dalam suatu karangan dapat ditangkap maknanya dalam pandangan sekilas, mencakup pesan yang tersirat dan tersurat (Ujang, 1988:20).

Topik adalah pokok pembicaraan atau sesuatu yang menjadi landasan penulisan suatu karangan atau artikel (AlGhiffari, 2010:1), sedangkan tema adalah amanat utama yang disampaikan oleh penulis melalui karangannya. Temamerupakan suatu hal menentukan arah tulisan atau tujuan dari penulisan artikel itu.Perbedaan topik dan tema adalah topikbersifat umum dan belum menggambarkan sudut pandang penulis, sedangkan temaberkenaan dengan suatu amanat utama yang disampaikan penulis melalui karangannya (Leksono, 2010:1).

Pada kenyataannya, sering ditemui kesulitan dalam proses belajar mengajar Bahasa Indonesia, terutama untuk materi membaca. Kesulitan-kesulitan yang menjadi kendala bagi siswa dalam membaca sebuah karangan, antara lain: (1) penjelasan teoritis guru yang tidak mampu memberikan pemahaman yang cukup bagi siswa; (2) penerapan pembelajaran suatu materi tidak disertai latihan dan strategi khusus untuk menggali pengetahuan lebih dalam mengenai materi yang diajarkan pada siswa; serta (3) strategi pembelajaran yang kurang melibatkan siswa akan menurunkan minat siswa, sehingga prestasi belajarnya pun akan mengalami penurunan. Suatu proses pembelajaran dapat berhasil jika didukung oleh metode pembelajaran yang berkualitas, yaitu metode yang dapat mengaktifkan siswa dan guru bertindak sebagai fasilitator saja sehingga siswa dapat menggunakan seluruh kemampuannya baik kognitif, psikomotorik maupun afektif.

Menurut Slavin (2008), Cooperative

Learning merupakan suatu teknik pembelajaran yang berusaha meningkatkan kemampuan siswa untuk bekerjasama dalam kelompok kecil, guna memaksimalkan kemampuan belajarnya, dan belajar dari temannya serta memimpin dirinya. Model pembelajaran yang cukup efektif dan kooperatif adalah model pembelajaran STAD (Student Teams Achivement Devisions). Model pembelajaran ini merupakan model pembelajaran yang menempatkan empat sampai lima orang siswa yang merupakan campuran dari kemampuan akademik, ras, atau jenis kelamin yang berbeda (Slavin dalam Asma, 2006:51).

Hasil penelitian yang telah dilakukan oleh Efi (2007) menyatakan bahwa pembelajaran dengan menggunakan model pembelajaran STAD, siswa merasa cukup terbantu dalam memahami pelajaran dan cukup menyukai teknik pembelajaran yang baru. Oleh sebab itu, peneliti mengangkat model pembelajaran STAD untuk diterapkan dalam pembelajaran membaca karangan dan menentukan tema dan topik pada siswa kelas IV dalam upaya meningkatkan kompetensi siswa dalam pelajaran Bahasa Indonesia.

Berdasarkan uraian di atas penulis mencoba melakukan penelitian tindakan kelas dengan mengangkat judul penelitian "PENERAPAN PEMBELAJARAN KOOPERATIF MODEL STAD UNTUK MENINGKATKAN KEMAMPUAN MENENTUKAN TOPIK DAN TEMA DALAM SUATU KARANGAN PADA SISWA KELAS IV SDN KEBUNAN I SUMENEP TAHUN PELAJARAN 2010$2011 ”$.

\section{METODE PENELITIAN}

Jenis penelitian ini merupakan Penelitian Tindakan Kelas (PTK). Penelitian ini mengikuti suatu daur (siklus) yang didalamnya terdapat empat komponen, yaitu perencanaan, pelaksanaan tindakan, observasi, dan refleksi (Susilo, 2008).

Pendekatan yang dipilih dalam penelitian ini adalah pendekatan kualitatif 
jenis PTK. Kehadiran peneliti sangat penting karena sebagai instrument yang utama sebagai (1) perencana kegiatan, (2) pengumpul data, (3) penganalisis data, (4) pelapor hasil penelitian, dan (5) sebagai guru.

Penelitian dilaksanakan di kelas IV SDN Kebunan I, jalan Raya Manding no. 40 Kecamatan Kota Sumenep, pada semester 2 tahun pelajaran 2010/2011. Subjek penelitian ini adalah siswa-siswa kelas IV yang berjumlah 46 anak.

Penelitian ini dilaksanakan dalam dua siklus, masing-masing siklus terdiri dari 4 tahap yaitu perencanaan tindakan (planning), pelaksanaan tindakan (action), observasi (observation), dan refleksi (reflection). Pelaksanaan siklus II dilaksanakan setelah mempelajari hasil refleksi pada siklus I.

\section{HASIL DAN PEMBAHASAN}

Hasil analisis data menunjukkan nilai rata-rata kelas dari siklus I dan siklus II pembelajaran bahasa Indonesia siswa kelas IV dengan teknik STAD mengalami peningkatan, yaitu nilai di atas KKM siklus II (35 anak) lebih tinggi dibanding pada siklus I (14 anak). Hal ini menunjukan bahwa terdapat peningkatan hasil belajar siswa dalam mata pelajaran bahasa Indonesia, hal ini disebabkan teknik STAD adalah teknik dengan konsep pemberian tanggung jawab yaitu dengan memahamidan menyelesaikan suatu tugas secara bersama-sama.

Data nilai Lembar Kerja Siswa secara individu pada siklus II menunjukkan bahwa indikator keberhasilan (tuntas) belum dicapai. Hal ini ditunjukkan dari persentase jumlah siswa yang memiliki nilai di bawah KKM lebih dari 20\%, yaitu 11 anak. Untuk memperbaiki hal tersebut, maka dilakukan remidi (perbaikan) bagi 11 siswa tersebut. Hal ini dilakukan untuk menuntaskan nilai sehingga berada di atas KKM. Jenis soal yang diberikan sama dengan pada Siklus I dan II, hanya berbeda karangan saja. Hasil dari remidi ini dapat dilihat pada Tabel 1.

Tabel 1Data nilai Lembar Kerja Siswa pada Tahap Remidi (Individu)

\begin{tabular}{|c|l|c|c|c|c|}
\hline \multirow{2}{*}{ No } & \multicolumn{2}{|c|}{$\begin{array}{c}\text { Nama } \\
\text { siswa }\end{array}$} & \multicolumn{4}{|c|}{ Nilai } \\
\cline { 3 - 6 } & Siklus 2 & Keterangan & Remidi & Keterangan \\
\hline 4 & Helen Nindya & 50 & Belum Tuntas & 100 & Tuntas \\
\hline 5 & Sindi Eka L. & 50 & Belum Tuntas & 75 & Tuntas \\
\hline 6 & Hairil & 50 & Belum Tuntas & 50 & Belum Tuntas \\
\hline 10 & Siti Holifah & 50 & Belum Tuntas & 50 & Belum Tuntas \\
\hline 15 & Indah Safitri & 50 & Belum Tuntas & 75 & Tuntas \\
\hline 16 & Ach. Hodaifi & 50 & Belum Tuntas & 75 & Tuntas \\
\hline 35 & Ani Ari F. & 50 & Belum Tuntas & 100 & Tuntas \\
\hline 36 & Dwi O. P. & 50 & Belum Tuntas & 100 & Tuntas \\
\hline 39 & Nur M. Rafi & 50 & Belum Tuntas & 50 & Belum Tuntas \\
\hline 42 & Moh. Fiqih & 50 & Belum Tuntas & 100 & Tuntas \\
\hline 43 & Rifqi Syarif H. & 50 & Belum Tuntas & 75 & Tuntas \\
\hline
\end{tabular}

Tabel 1 menunjukkan bahwa jumlah siswa yang dikategorikan tuntas telah meningkat. Hal ini ditunjukkan dari jumlah siswa yang berhasil mencapai nilai di atas KKM adalah 8 anak. Jumlah siswa yang masih belum mendapatkan nilai di atas KKM sebanyak 3 anak. Meskipun masih terdapat siswa yang belum tuntas, tetapi dilihat dari persentase jumlah siswa yang mendapat nilai di atas KKM mencapai lebih dari $80 \%$. Persentase ini menunjukkan bahwa remidi yang dilakukan dalam teknik pembelajaran ini berhasil meningkatkan kemampuan siswa dalm menentukan topik dan tema suatu karangan. 
Namun pada dasarnya teknik dari pendekatan pembelajaran kooperatiftersebut dapat merangsang siswa terlibat secara aktif untuk bekerjasama, berdiskusidan saling membantu antar anggota kelompok dalam belajar sehingga mereka dapat menciptakan pemahaman mereka secara bersama-sama.Walaupun, masihterdapat siswa yang masih enggan terlibat aktif dalam pembelajaran. Hal ini dapatdilihat pada hasil lembar observasi dan angket yang menunjukkan bahwa merekamenyukai teknik pembelajaran ini namun belum terbiasa karena teknikini masih baru bagi mereka.

Untuk hasil observasi, baik dari performa siswa dan kelompok maupun keterlaksanaan pembelajaran menunjukkan bahwa performa siswa dan kelompok dapat terlihat baik dengan beberapa indiikator yang telah ditentukan.Indikator yang memiliki nilai rendah adalah keaktifan (untuk individu) dan aspek akuntabilitas individu (untuk kelompok).Hal ini dipengaruhi oleh kemampuan tiap-tiap individu yang berbeda, sehingga banyak siswa yang masih pasif dalam diskusi kelas maupun kelompok.Sedangkan, untuk observasi keterlaksaan pembelajaran menunjukkan bahwa semua rencana yang telah ditentukan dapat dilaksanakan dengan baik sesuai dengan alokasi waktu.

Dalam teknik pembelajaran tersebut, siswa yang biasanya belajar secaraindividu, tanpa kompetisi dan penghargaan dicoba dikondisikan dengan adanyakompetisi dan penghargaan yang menjadi motivasi bagi keberhasilan belajar mereka,serta suasana pembelajaran dapat menjadi lebih hidup dan bervariasi.Teknik pembelajaran ini juga dapat menciptakan suasana kegiatan belajar mengajar yangbaik, karena siswa tidak cepat merasa bosan dalam belajar dan dapat meningkatkanrasa percaya diri tiap siswa karena siswa dilatih untuk aktif berpendapat, menghargaiperbedaan pendapat dan termotivasi untuk meningkatkan prestasinya karena adanyapersaingan dan penghargaan yang diberikan.

Hasil penelitian ini sejalan pula dengan hasil penelitian yang dilakukan oleh Efi (2007)yang menyatakan bahwa hasil belajar siswa yang diajarkan dengan menggunakanteknik pembelajaran kooperatiflebih baik dibandingkan dengan hasil belajar siswa yang diajarkan dengan menggunakan pembelajaran konvensional.Sedangkan Daroni (2002) dalampenelitiannya menyatakan bahwa dengan pendekatan pembelajaran kooperatif memiliki keuntungan dalam prestasi akademis, motivasi instrinsik danketerampilan bekerjasama yang baik.Predy Karuru (2006) menyimpulkan bahwa dengan menggunakan seting pembelajarankooperatif tipe STAD dapat meningkatkan minat dan proporsi jawaban benar danhasil belajar siswa lebih baik dari pada dengan menggunakan metode atau setingpembelajaran ceramah atau teacher centered.

\section{KESIMPULAN DAN SARAN \\ 4.1 Kesimpulan}

Berdasarkan hasil dan pembahasan penelitian dapat disimpulkan bahwa: 1) Terdapat peningkatan nilai di atas KKM siswa kelas IV SDN Kebunan I untuk materi pokok menentukan topik atau tema mata pelajaran bahasa Indonesia dengan pendekatan teknik pembelajaran kooperatif STAD (cooperative learning) dari 14 anak menjadi 43 anak; 2)Hasil observasi terhadap performa siswa, baik secara individu maupun kelompok menunjukkan hasil nilai di atas KKM $(>60,00)$. Hal ini ditunjukkan dari ratarata nilai individu sebesar 73,15 dan nilai kelompok 86, 11 dari total nilai 100 dengan beberapa indikator yang telah ditentukan. Di antaranya, untuk performa siswa (individu): (a) rasa ingin tahu; (b) keaktifan; (c) keberanian; dan (d) sifat menghargai. Sedangkan indikator untuk performa siswa (kelompok) : (a) saling ketergantungan; (b) interaksi tatap muka; 
(c) akuntabilitas individu; dan (d) keterampilan menjalin hubungan antar individu; dan 3) Respon siswa terhadap materi pembelajaran menentukan topik atau tema dalam bahasa Indonesia melalui pendekatan pembelajaran kooperatif (Cooperative Learning) teknik STAD menunjukkan bahwa umumnya para siswa menyukai teknik ini karena memberikan suasana baru dan terdapat penghargaan yang dapat memotivasi mereka dalam belajar, namun para siswa menyatakan juga belum terbiasa karena kedua teknik ini masih baru bagi mereka.

\subsection{Saran}

Berdasarkan kesimpulan di atas, saran dalam penelitian ini adalah: 1) Perlu adanya penelitian lebih lanjut untuk mengetahui apakah pendekatan pembelajaran STAD dapat diterapkan serta memberikan hasil yang lebih baik pada topik maupun mata pelajaran yang lain untuk meningkatkan motivasi belajar yang lebih baik lagi bagi siswa; 2) Guru diharapkan memiliki pengetahuan dan kemampuan yang cukup untuk memilih metode ataupun teknik pembelajaran yang tepat dan sesuai dengan materi yang akan diajarkan sehingga dapat meningkatkan hasil belajar siswa.

\section{DAFTAR PUSTAKA}

Abdurrahman, $\quad$ Bintoro. 2000. Pembelajaran Kooperatif.Bandung: Penerbit Nusa Media.

Adiwimarta, Sri sukesih; Hermanoe Maulana; Adi Sunaryo; Sri Timur Suratman. 1988. Kamus Besar Bahasa Indonesia. Balai pustaka :Jakarta.

Al-Ghiffari, Abu. 2010. Optimalisasi Potensi Menulis. www.penulissukses.com. Diakses tanggal 20 Januari 2011 pukul 10:36.
Asma, Nur. 2006. Model Pembelajaran Kooperatif. Jakarta: Departemen Pendidikan Nasional

Daroni. 2002. Pembelajaran Kooperatif IPA di SLTP Melalui Model Jigsaw. Lembaga Ilmu Kependidikan Universitas Negeri Semarang. Th. XXXI No.2

Efi. 2007. Perbedaan Hasil Belajar Biologi Antara Siswa Yang Diajar Melalui Pendekatan Cooperatif Learning Teknik Jigsaw dengan Teknik STAD. Skripsi Fakultas Pendidikan Ilmu Alam, Universitas Islam Negeri Syarif Hidayatullah.

Fahruddin, L. 1988. Menulis Paragraf. Solo:Penerbit Rusdakarya.

Friza, 2009. Topik dan Judul Karangan. http://freezcha.wordpress.com/2009/ 11/15/topik-dan-judul-karangan/.

Diakses tanggal 19 Januari 2011 pukul 12:49.

Hasibuan. 2008. Proses Belajar Mengajar. Bandung: Penerbit Rosdakarya.

Isnaini, Salwa. 2007. Peningkatan Pembelajaran Membaca Siswa Kelas VI SDN Kolor II dengan Menerapkan Metode Pembelajaran Kooperatif Tipe Jigsaw. Skripsi. Jurusan Pendidikan Bahasa dan Sastra Indonesia. STKIP PGRI Sumenep.

Keraf, Gorys. 1989. Komposisi. Flores: Percetakan Arnoldus.

Larasati, Riska N. S. 2005. Analisis Metode Pembelajaran Kooperatif Tipe STAD Dan Pengaruhnya Terhadap Upaya Peningkatan Hasil Belajar Akuntansi Dalam Pokok Bahasan Pencatatan Transaksi 
Dagang Mata Pelajaran Akuntasi Pada Siswa Kelas II Semester I SMU Negeri 7 Purworejo. Skripsi Fakultas Ilmu Sosial Universitas Negeri Semarang 2005

Leksono, Shiddiq. 2010. Topik, Tema, dan Judul dalam Bahasa Indonesia. Jakarta :Universitas Gunadarma.

Masruroh, Imroatin. 2009. Meningkatkan Kemampuan Menemukan Kalimat Utama Melalui Model Pembelajaran STAD (Student Team Achievement Division) Di Kelas IV SDN Cangkringmalang III Kabupaten Pasuruan. Skripsi Program Studi S1 Pendidikan Guru Sekolah Dasar. Malang: Universitas Negeri Malang.

Masturoh. 2005. Pengaruh Cooperatif Learning dengan Model Jigsaw Terhadap Hasil Belajar Matematika. Skripsi FTIK UIN Syarif Hidayatullah, Jakarta.

Nurinsani, Devita. 2010. Tema, Topik dan Judul.http://ita-kyu-

kiyut.blogspot.com/2010/01/ragambahasa-tugas-kelompok.html.

Diakses tanggal 20 Januari 2011 pukul 10:34.

Nurhadi, Yasin 2004. Pembelajaran Kontektual Dan Penerapannya. Malang: Universitas Negeri Malang.

Nurhadi, Yasin 2004. Pembelajaran Kontektual Dan Penerapannya. Malang: Universitas Negeri Malang.

Nurmaniyatin, Siti. 2008. Peningkatan Daya Nalar dalam Menulis Wacana Argumentasi melalui Pengembangan Tema pada Siswa Kelas V SDN Tana Merah II Kecamatan Saronggi-Sumenep. Skripsi. Jurusan Pendidikan Bahasa dan Sastra Indonesia. STKIP PGRI Sumenep.

Predy Karuru. 2006. Penerapan Keterampilan Proses dalam Setting Pembelajaran Kooperatif Tipe STA untuk Meningkatkan Kualitas Pembelajaran IPA Siswa SLTP.http://depdiknas.go.id/Jurnal/ 2003/45/predy_Karuru.htm. Diakses tanggal 3 Januari 2011.

Sunarno. 2007.2 Jenis Karangan.http://sunarno5.wordpres s.com/2007/12/06/jenis-karangan/. Diakses tanggal 20 Januari pukul $10: 31$

Susilo, H; Chotimah, H; Dwitasari, Y. 2008. Penelitian Tindakan Kelas Sebagai Sarana Pengembangan Keprofesionalan Guru Dan Calon Guru. Malang: Bayumedia Publishing.

Susilowati, Cici. 2008. Peningkatan Keterampilan Membaca Pemahaman dengan Metode SQ3R Siswa Kelas VIII di UPTD SMPN 2 Kalianget. Skripsi. Jurusan Pendidikan Bahasa dan Sastra Indonesia. STKIP PGRI Sumenep.

Tarigan, Djago. 1987. Membina Keterampilan Menulis Paragraf Dan Pengembangannya. Bandung: Percetakan Angkasa.

Tarigan, Hendri Guntur. 1986. Membaca: Sebagai Suatu Keterampilan Berbicara. Percetakan Angkasa. Bandung.

Ujang. 1988. Prinsip-Prinsip Dasar Sastra. Bandung: Penerbit Angkasa.

Zakiyah, Ainiz. 2008. Hubungan antara Kegemaran Membaca dengan Prestasi Belajar Bahasa Indonesia Siswa Kelas IV SDN Kambingan 
Timur Kecamatan Saronggi

Kabupaten Sumenep. Skripsi.

Jurusan Pendidikan Bahasa dan

Sastra Indonesia. STKIP PGRI

Sumenep. 